\title{
JM
}

Volume 5 No. 1 (Juli 2017)

(C) The Author(s)

\section{GAMBARAN PENGETAHUAN DAN KECEMASAN IBU HAMIL TRIMESTER III DALAM MENGHADAPI PERSALINAN DI WILAYAH KERJA PUSKESMAS MUARA AMAN KECAMATAN LEBONG UTARA, KABUPATEN LEBONG TAHUN 2016}

\author{
DESCRIPTION OF KNOWLEDGE AND ANXIOUS OF WOMAN PREGNANT OF \\ TRIMESTER III IN CONSIDERING LABOR AT THE WORKING AREA OF MUARA \\ AMAN PUBLIC HEALTH CENTER IN NORTH LEBONG DISTRICT \\ LEBONG REGENCY 2016
}

ICE RAKIZAH SYAFRIE AKADEMI KEBIDANAN DEHASEN BENGKULU, Email: STIKES_DEHASEN@YAHOO.CO.ID, HP: 0811731607

\begin{abstract}
ABSTRAK
Persalinan merupakan suatu proses fisiologis yang terjadi pada setiap wanita, namun wanita dalam menghadapi persalinan sebagian besar selalu mengalami kecemasan karena berbagai faktor, salah satunya yaitu minimnya pengetahuan tentang persalinan. Di Indonesia tahun 2015 prevalensi risiko kejadian depresi atau kecemasan dalam menghadapi persalinan pervaginam sebesar 10-25\%, kejadian depresi atau kecemasan mempersulit proses persalinan sekitar 10$15 \%$. Penelitian ini bertujuan untuk mengetahui gambaran pengetahuan dan kecemasan ibu hamil trimester III pada persalinan.Jenis penelitian ini bersifat deskriptif dengan pengumpulan data primer yang diperoleh secara langsung dari responden, dengan tehnik random sampling dengan cara memberikan kuisioner. Penelitian ini dilaksanakan di Puskesmas Muara Aman Kabupaten Lebong Tahun 2016.Sampel yang digunakan sebanyak 22 orang. Sebagian besar $(54,5 \%)$ ibu hamil memiliki pengetahuan cukup dan hampir sebagian $(45,5 \%)$ ibu hamil cemas sedang. Di harapkan kepada pihak Puskesmas untuk terus memberikan pendidikan kesehatan tentang kehamilan dan persiapan persalinan agar ibu hamil tidak hanya tahu tentang kehamilan tapi juga mampu mengatasi kecemasan yang dialami selama menghadapi persalinan.
\end{abstract}

Kata kunci : pengetahuan, kecemasan, persalinan

\begin{abstract}
Labor is a physiological process that occurs in every woman, but women in the face of childbirth is mostly always anxious because of various factors, one of which is the lack of knowledge about childbirth. In Indonesia in 2015 the prevalence of the risk of depression or anxiety events in dealing with vaginal delivery of $10-25 \%$, the incidence of depression or anxiety complicates the birth process of about $10-15 \%$. This study aims to determine the description of knowledge and anxiety of pregnant women of trimester III in labor. This type of research is descriptive with primary data collection obtained directly from respondents, with random sampling technique by giving questionnaires. This research was conducted at Muara Aman Public Health Center of Lebong Regency in 2016. The sample used was 22 people. Most $(54.5 \%)$ of pregnant women have knowledge enough and almost half $(45,5 \%)$ pregnant women
\end{abstract}


are of medium anxiety. In the hope to the public health center to continue to provide of health education about pregnancy and delivery preparation so that pregnant women not only know about pregnancy but also able to overcome the anxiety experienced during the birth.

Keywords: knowledge, anxiety, labor

\section{PENDAHULUAN}

Dalam rencana strategi nasional Making Pregnancy Safer (MPS), bahwa visi rencana pembangunan kesehatan menuju Indonesia sehat 2025 adalah kehamilan dan persalinan di Indonesia berlangsung aman, dengan misi nya menurunkan kesakitan dan kematian maternal dan neonatal. Sejalan dengan hal tersebut, di masyarakat paradigma persalinan itu merupakan pertaruhan hidup dan mati, sehingga wanita yang akan melahirkan mengalami ketakutan-ketakutan, khususnya takut mati baik bagi dirinya sendiri ataupun bayi yang akan dilahirkannya (Kartini, 2010).

Angka Kematian Ibu (AKI) merupakan salah satu indikator dalam menentukan derajat kesehatan masyarakat. Data WHO, UNICEF, UNFPA dan Bank Dunia menunjukkan angka kematian ibu tahun 2014 sebanyak 536.000 perempuan meninggal dunia akibat masalah persalinan, lebih rendah dari jumlah kematian ibu tahun 2015 dan sebanyak 576.000. Menurut data WHO sebanyak 91\% kematian ibu akibat masalah persalinan atau kelahiran terjadi di Negaranegara berkembang (Depkes RI, 2015).

Berdasarkan data WHO (2009) di Amerika Serikat menganalisis data dari 35.539 pasien bedah dirawat di unit perawatan intensif tahun 2008 terdapat 27,3\% mengalami kondisi kejiwaan dan 21,9\% pasien mengalami kecemasan, sedangkan tahun 2009 dari 8.922 pasien terdapat $25,1 \%$ mengalami kondisi kejiwaan dan 26,9\% mengalami kecemasan (Depkes RI, 2015).

Kecemasan dalam menghadapi persalinan memang tidak berdampak langsung terhadap kematian namun kecemasan dalam persalinan memberi efek gelisah, dan aktifitas saraf autonom dalam merespon terhadap ancaman yang tidak jelas yang individu rasakan, sehingga menghambat proses persalinan (Suliswati, 2010).
Angka kematian ibu dan anak di Indonesia masih menjadi salah satu yang tertinggi di Asia. Tahun 2015, angka kematian ibu saat melahirkan mencapai 307 per 100.000 kelahiran hidup. Angka ini 12 kali lebih tinggi dibandingkan Singapura, 9 kali lebih tinggi dibandingkan dengan Malaysia dan 3 kali lebih tinggi dibanding Filipina. Rata-rata angka kematian ibu di dunia mencapai 400.000 per 100.000 kelahiran hidup tahun 2006. Pemerintah menargetkan untuk mengurangi angka kematian ibu dari 390 per 100.000 kelahiran hidup menjadi 225 per 100.000 di tahun 2010 dan menargetkan menjadi 225 per 100.000 di tahun 2025 (Depkes RI, 2015).

Di Indonesia pada tahun 2015 prevalensi risiko kejadian depresi atau kecemasan dalam menghadapi persalinan pervaginam sebesar $10-25 \%$ yang banyak terjadi pada wanita umur 20-44 tahun. Kejadian depresi atau kecemasan mempersulit proses persalinan sekitar $10-15 \%$, sedangkan kecemasan yang terjadi pada pasien operasi seksio sesarea sekitar 15-25\% (Ahmad, 2014).

Angka kematian kelahiran pervaginam 95-120 per 100.000 kelahiran hidup pada tahun 2014 di Indonesia, sedangkan angka kematian operasi seksio sesarea di Indonesia tahun 2014 adalah 112-130 tiap 100.000 kelahiran hidup, melihat besarnya resiko yang mugkin ditimbulkan pada saat persalinan baik operasi seksio sesarea maupun pervaginam, maka hal ini dapat menyebabkan kecemasan pada pasien yang akan menghadapi persalinan (Pusdiknakes, 2014).

Ada beberapa hal yang menjadi penyebab ketakutan tersebut, yang pertama adalah kenyataan bahwa adanya rumor bahwa persalinan itu sangat sakit, bahkan ada beberapa kasus di mana sang ibu meninggal dunia karena proses persalinan. Ada juga ketakukan yang berhubungan dengan pembiayaan persalinan tersebut yang nanti 
nya setelah proses persalinan ternyata dana yang dikeluarkan tidak sesuai dengan yang di prediksi oleh calon ibu. Selain itu untuk calon ibu yang baru pertama hamil, sang calon ibu baru mengalami persiapan persalinan untuk pertama kalinya, jika kita belum pernah menjalani sesuatu, memang kita akan cenderung untuk merasa takut. Intinya, persalinan bisa menjadi momok yang sangat menakutkan. Salah satu tindakan untuk mengurangi tingkat kecemasan adalah dengan mempersiapkan mental pasien. Persiapan mental yang kurang memadai dapat mempengaruhi pengambilan keputusan pasien dan keluarga ( Proverawati.A, 2010 ).

Kecemasan pada ibu bersalin bisa berdampak meningkatnya sekresi adrenalin. Salah satu efek adrenalin adalah konstriksi pembuluh darah sehingga suplai oksigen ke janin menurun. Penurunan aliran darah juga menyebabkan melemahnya kontraksi rahim dan berakibat memanjangnya proses persalinan. Tidak hanya sekresi adrenalin yang meningkat tetapi sekresi ACTH (Adrenocorticotropichormone) juga meningkat, menyebabkan peningkatan kadar kortisol serum dan gula darah. Kecemasan dapat timbul dari reaksi seseorang terhadap nyeri. Hal ini akan meningkatkan aktifitas saraf simpatik dan meningkatkan sekresi katekolamin.

Sekresi katekolamin yang berlebihan akan menimbulkan penurunan aliran darah ke plasenta sehinga membatasi suplai oksigen ke janin serta penurunan efektifitas dari kontraksi uterus yang dapat memperlambat proses persalinan (Poverawati.A, 2015).

Tingkat kecemasan yang dialami pasien dapat dipengaruhi oleh pendidikan, dimana tingkat pendidikan yang tinggi akan memperluas pandangan dan ruang lingkup pergaulan, sehingga tingkat pendidikan yang lebih tinggi akan mempermudah responden untuk menerima informasi tentang kesehatan dan dapat menurunkan tingkat kecemasan dibandingkan dengan yang berperdidikan sedang dan rendah. Demikian pula dengan pengetahuan semakin baik pengetahuan seseorang maka semakin baik pola fikirnya.
Ini dapat diartikan bahwa semakin tinggi pendidikan, dan pengetahuan memudahkan seseorang menerima informasi yang berhubungan dengan persiapan persalinan sehingga meminimalkan respon dari tingkat kecemasan (Soewandi, 2013).

Di Provinsi Bengkulu pada tahun 2015 jumlah kematian ibu sebanyak 45 orang dari $39.163 \mathrm{ibu}$ hamil yang terdiri dari ibu hamil 18 orang, ibu bersalin 11 orang dan ibu nifas sebanyak 16 orang. Angka kematian ibu di provinsi Bengkulu tahun 2015 sebesar 48 orang, sedikit mengalami kenaikan dimana pada tahun 2016 angka kematian ibu meningkat sebesar 122 per 100.000 kelahiran hidup. Pada tahun 2013 terdapat pasien mengalami kondisi kejiwaan 12,2 \% dan pasien yang mengalami kecemasan 15,1\% dari 30.531 ibu hamil (DinKes Provinsi Bengkulu, 2016).

Berdasarkan data yang diperoleh dari Dinas Kesehatan Kabupaten Lebong dari 14 Puskesmas yang ada di Kota Lebong, cakupan ibu hamil pada tahun 2013, dimana angka tertinggi di Kecamatan Lebong Utara Puskesmas Muara Aman berjumlah 307 orang dengan kunjungan K1 berjumlah 302 orang dan K4 berjumlah 300 orang (DinKes Kabupaten Lebong, 2016).

Berdasarkan data yang diperoleh dari Puskesmas Muara Aman Kabupaten Lebong cakupan ibu hamil pada bulan Maret tahun 2016 dengan kunjungan K1 berjumlah 31 orang dan K4 berjumlah 24 orang. Dimana terdapat 67 orang yang berkunjung yang terdiri dari 25 orang ibu hamil trimester I, 14 orang ibu hamil trimester ke II, 28 orang ibu hamil trimester ke III (Laporan kegiatan PWS-KIA Puskesmas Muara Aman Kabupaten Lebong, Maret 2016).

Berdasarkan hasil survei awal yang peneliti lakukan terhadap ibu hamil TM III dari tanggal 07 April sampai 12 April 2016 di yang dilakukan peneliti terhadap 10 orang ibu hamil TM III, ternyata 5 orang mengaku cemas menghadapi persalinan, dan 2 orang di antaranya mengaku cemas berat sampai berencana memilih bersalin dengan cara operasi cesarea karna menganggap persalinan 
pervaginam itu sakit dan 3 orang tidak mengalami kecemasan. Ternyata penyebab utama kecemasan yang dialami pasien adalah kurangnya dukungan dari keluarga dan kurangnya informasi yang didapat dari petugas kesehatan dan kurang antusias nya pasien untuk bertanya.

Berdasarkan data di atas peneliti tertarik untuk meneliti mengenai Gambaran Pengetahuan dan Kecemasan Ibu Hamil Trimester III dalam Menghadapi Persalinan di Wilayah Kerja Puskesmas Muara Aman Kecamatan Lebong Utara Kabupaten Lebong Tahun 2016.

\section{METODE PENELITIAN}

Desain penelitian ini menggunakan metode deskriptif dengan desain deskriptif yaitu suatu metode penelitian yang dilakukan terhadap variabel tanpa membuat atau menghubungkan variabel yang lain.

Adapun yang menjadi populasi adalah seluruh ibu hamil TM III yang berkunjung ke Puskesmas Muara Aman dan ke Posyandu wilayah kerja Puskesmas Muara Aman Kecamatan Lebong Utara bulan Maret tahun 2016 yaitu 28 orang.

Sampel yang dalam penelitian ini yaitu ibu hamil TM III yang berkunjung ke Puskesmas Muara Aman dan Posyandu di wilayah kerja puskesmas Muara Aman yang berjumlah 22 responden.

\section{HASIL PENELITIAN}

\section{Pengetahuan}

Tabel 1. Distribusi pengetahuan Ibu hamil Trimester III dalam menghadapi persalinan di wilayah kerja puskesmas Muara Aman kecamatan Lebong Utara Kabupaten Lebong Tahun 2016

\begin{tabular}{cccc}
\hline No & Variabel & Frekuensi & $\begin{array}{c}\text { Persentase } \\
(\%)\end{array}$ \\
\hline 1 & $\begin{array}{c}\text { Pengetahuan } \\
\text { Kurang }\end{array}$ & 7 & 31.8 \\
\hline 2 & Pengetahuan & 12 & 54.5 \\
\hline
\end{tabular}

\begin{tabular}{cccc}
\hline \multicolumn{4}{c}{ Cukup } \\
\\
\hline 3 & $\begin{array}{c}\text { Pengetahuan } \\
\text { Baik }\end{array}$ & 3 & 13.6 \\
\hline 4 & Total & 22 & 100.0 \\
\hline
\end{tabular}

Hasil penelitian ini menunjukkan bahwa dari 22 responden, hampir sebagian $(31,8 \%)$ memiliki pengetahuan kurang, hal ini disebabkan karena masih ada warga di wilayah Muara Aman yang tinggal di Kebun sehingga jarang terpapar dengan pendidikan kesehatan dari tenaga kesehatan dan masih ada jarak tempuh dari rumah ke puskesmas yang terlalu jauh, sehingga jika sakit warga cukup berobat sendiri dengan obat herbal atau datang ke dukun. Sebagian besar $(54,5 \%)$ memiliki pengetahuan cukup karena rata-rata warga di wilayah kerja puskesmas Muara Aman memiliki pendidikan SMP dan SMA sehingga pendidikan kesehatan yang disampaikan oleh tenaga kesehatan lebih mudah diterima dan sebagian kecil $(13,6 \%)$ memiliki pengetahuan baik, setelah di tanya oleh peneliti hal ini disebabkan karena 2 orang ibu hamil adalah tenaga kesehatan dan 1 orang nya lagi memiliki pendidikan Diploma.

Hasil penelitian ini sejalan dengan penelitian yang dilakukan oleh Rihana (2012) dengan judul "Gambaran pengetahuan dan Tingkat Stres pada Ibu Hamil Primipara dalam Menghadapi Persalinan Normal di Ruang Poli Kebidanan RSUD Sorong" di dapat bahwa sebagianbesar ibu hamil memiliki pengetahuan cukup.

Hasil penelitian ini didukung oleh pendapat Amalia (2009), yang mengatakan bahwa menjelang persalinan, banyak hal mengkhawatirkan muncul pada pikiran ibu, seperti takut bayi cacat, takut harus operasi, takut persalinannya lama, takut tidak ada yang mendampinginya pada saat proses persalinan nanti dan lain sebagainya. Calon ibu yang mengandung anak pertama biasanya mengalami beberapa gangguan psikologi seperti stres dan semakin meningkat saat usia kehamilan makin bertambah dan mendekati proses persalinan.

Pada kehamilan trimester tiga ibu hamil 
sudah mulai menimbulkan kecemasan, apalagi menjelang persalinan pertama. Perasaan stress yang akan timbul misalnya seperti pertanyaan dan bayangan apakah dapat melahirkan normal, cara mengejan, nyeri persalinan, apakah akan terjadi sesuatu pada saat melahirkan, dan apakah bayi yang akan lahir selamat dan normal.

\section{Kecemasan}

Tabel 2. Distribusi kecemasan Ibu hamil Trimester III dalam menghadapi persalinan di wilayah kerja puskesmas Muara Aman Kecamatan Lebong Utara Kabupaten Lebong Tahun 2016

\begin{tabular}{cccc}
\hline No & Variabel & Frekuensi Persentase (\%) \\
\hline 1 & Cemas Berat & 2 & 9.1 \\
\hline 2 & Cemas Sedang & 10 & 45.5 \\
\hline 3 & Cemas Ringan & 8 & 36.4 \\
\hline 4 & Tidak Cemas & 2 & 9.1 \\
\hline 5 & Total & 22 & 100 \\
\hline
\end{tabular}

Hasil penelitian ini menunjukkan bahwa dari 22 responden, sebagian kecil $(9,1 \%)$ ibu hamil cemas berat, hal ini disebabkan karna responden lebih banyak mendapatkan informasi dari teman atau tetangga, rata-rata setiap pengalaman bersalin yang diceritakan oleh orang lain yang bukan tenaga kesehatan sehingga cerita yang didengar memberikan kesan bahwa persalinan itu mengerikan dan sangat sakit, terutama bagi ibu hamil primipara. Sebagian $(45,5 \%)$ ibu hamil cemas sedang, hal ini disebabkan karena ibu sudah pernah terpapar dengan pendidikan kesehatan tentang persiapan persalinan dan fisiologi persalinan, hampir sebagian $(36,4 \%)$ ibu hamil cemas ringan hal ini disebabkan karna ibu sudah pernah terpapar dengan pendidikan kesehatan dan sudah menyiapkan betul untuk persalinannya seperti tempat bersalin, tabulin kendaraan dan donor darah, sebagian kecil $(9,1 \%)$ ibu hamil tidak cemas karna ibu sudah mengalami persalinan normal tanpa ada komplikasi jadi ibu sudah ada pengalaman sebelumnya dan sudah merasakan kalau persalinan itu tidak seburuk seperti yang dibayangkan sebelum melahirkan.

Sejalan dengan penelitian yang dilakukan oleh Ria Alfahrezy (2011) yang meneliti tentang "Faktor-faktor yang berhubungan dengan kecemasan Ibu Primipara dalam menghadapi persalinan Ruang CI Kebidanan RSUD Semarang” di dapat bahwa sebagian besar ibu hamil mengalami cemas sedang.

Umumnya seorang wanita yang akan melahirkan akan mengalami proses rasa sakit atau rasa nyeri. Jika wanita yang akan melahirkan tidak dapat menahan rasa nyeri dan dibiarkan, hal yang dicemaskan adalah konsentrasi calon ibu menghadapi atau selama proses persalinan terganggu. Hal ini sangat berbahaya bagi calon ibu atau pun bayinya, dan dapat menyebabkan kematian (Bramantyo, 2011)

Menurut Maulana (2013), kecemasan pada ibu hamil juga bisa timbul dikarenakan persepsi yang salah dan kurangnya pengetahuan tentang persalinan sehingga yang tertanam dibenak kebanyakan ibu cukup menyeramkan dan menakutkan). Stress yang berlebihan pada ibu hamil dapat menimbulkan kelelahan, ketidaknyamanan, gelisah, tidak bisa tidur nyenyak, mudah tersinggung, mudah sesak, tidak mampu memusatkan perhatian, ragu-ragu, tertekan, dan ingin lari dari kenyataan. Jika kekhawatiran dan stress ibu berlebihan bisa mempengaruhi keadaan ibu sehingga dapat merugikan ibu dan bayi

Selain itu menurut Simkin (2012), ketakutan, kecemasan, stress atau kemarahan yang berlebihan dapat menimbulkan kemajuan persalinan yang lambat. Perasaan lelah, takut, dan putus asa merupakan akibat dari pra persalinan atau fase laten yang memanjang. Wanita yang tidak didukung secara emosional, atau memiliki kesulitan dalam persalinan yang lalu dapat merasa cemasa dan takut mengahadapi persalinan, sehingga menyebabkan persalinan tanpa kemajuan yang berarti dan persalinan yang sangat nyeri.

Berdasarkan hasil pengumpulan data penelitian dapat diketahui bahwa hal yang 
paling sering dialami ibu adalah merasa takut tanpa alasan yang jelas dan menjadi mudah marah karena hal-hal sepele, hasil penelitian ini juga menunjukkan bahwa ibu yang mengalami cemas dapat terjadi karena mekanisme coping dalam menghadapi sesuatu masalah setiap individu berbeda-beda semua tergantung dari rasa penerimaan individu masing-masing dan tingkat pengetahuan masing-masing individu dalam mengatasi suatu masalah.

Berdasarkan hasil penelitian ini ada beberapa penjelasan diatas dapat disimpulkan bahwa pada ibu hamil sangat rentan mengalami gangguan kecemasan, hal ini dapat disebabkan oleh rasa kehawatiran ibu dengan kehamilannya misalnya dan rasa takut saat melahirkan nanti akan mengalami komplikasi sehingga harus di operasi walaupun ibu tersebut pernah mengalami kehamilan sebelumnya juga terkadang tidak bisa menerima dengan baik keadaan ini.

Maka dari itu diharapkan kepada petugas kesehatan terutama bidan dapat lebih meningkatkan pengetahuan ibu hamil mengenai proses kehamilan pada para ibu terutama pada ibu hamil dengan pengetahuan kurang sangat rentan mengalami kecemasan karena mepunyai pengalaman hamil sebelumnya. Untuk mengurangi kecemasan pada ibu hamil diharapkan kepada ibu dapat melakukan pemeriksaan atrenatal care (ANC) secara rutin minimal 4 kali dalam masa kehamilan yaitu trimester pertama 1 kali, trimester kedua 1 dan trimester ketiga 2 kali agar ibu dapat melihat perkembangan kehamilanya secara berkesinambungan dan apabila terjadi masalah-masalah pada kehamilanya dapat segera diatasi selain itu ibu juga akan mendapatkan informasi yang lebih baik saat melakukan ANC sehingga halhal dapat menimbulkan kegelisahan yang mengakibatkan tingkat stess pada ibu hamil dapat teratasi.

Selain itu diharapkan kepada bidan dapat berperan aktif dalam meminimalkan tingkat stress pada ibu hamil yang akan menjalani proses persalinan dengan mengajarkan latihan-latihan fisik, mengajarkan teknik-teknik relaksasi pada ibu hamil dan dapat juga dengan melakukan pelatihan hypnobirthing yang merupakan salah satu tehnik outohipnosis (selfhypnosis) atau swasugesti, dalam menghadapi dan menjalani kehamilan serta persiapan melahirkan sehingga para wanita hamil mampu melalui masa kehamilan dan persalinannya dengan cara yang alami, lancar, dan nyaman (tanpa rasa sakit) sehingga dengan peran-peran aktif ini dapat berdampak kepada penurunan tingkat stress ibu dalam menjani proses persalinan.

\section{KESIMPULAN}

Dari hasil penelitian tentang gambaran pengetahuan dan kecemasan ibu hamil trimester III dalam menghadapi persalinan di wilayah kerja Puskesmas Muara Aman Kecamatan Lebong Utara Kabupaten Lebong tahun 2016 dapat ditarik kesimpulan sebagai berikut:

1. Pengetahuan

Sebagian besar $(54,5 \%)$ ibu hamil memiliki pengetahuan cukup.

2. Kecemasan

Hampir sebagian (45,5\%) ibu hamil cemas sedang.

\section{SARAN}

Berdasarkan hasil penelitian yang telah dilakukan maka peneliti memberi saran kepada:

\section{Bagi peneliti}

Dari penelitian yang dilakukan oleh peneliti, peneliti berharap dapat menambahkan ilmu pengetahuan dan wawasan yang lebih dalam lagi tentang pengetahuan dan kecemasan ibu hamil dalam menghadapi persalinan, dan dapat menerapkan ilmu yang peneliti dapat di lapangan. 


\section{Puskesmas Muara Aman}

Peneliti mengharapkan dari hasil penelitan ini dapat memberikan masukan bagi petugas Puskesmas dan bidan dalam membuat kebijakan institusi terkait dalam upaya pelaksanaan peningkatan mutu pelayanan kesehatan ditinjau dari peningkatan pengetahuan ibu hamil tentang persiapan persalinan melalui konseling atau pendidikan kesehatan agar ibu hamil tidak hanya tahu tentang kehamilan tapi juga mampu mengatasi kecemasan yang dialami selama menghadapi persalinan.

3. Peneliti Selanjutnya

Diharapkan hasil penelitian ini dapat dijadikan sebagai dasar untuk melakukan penelitian berikutnya dan kepada peneliti selanjutnya diharapkan dapat mengembangkan penelitian ini dengan desain penelitian lain dengan melihat adanya hubungan antara variabel dengan menentukan variabel yang dapat mempengaruhi tingkat kecemasan ibu hamil dalam menghadapi persalinan dengan memperluas ruang lingkup penelitian dengan jumlah sampel yang lebih banyak agar didapat hasil yang lebih memuaskan. Juga diharapkan sebagai referensi, sumber bahan bacaan dan bahan pengajaran terutama yang berkaitan dengan tingkat kecemasan pada ibu dalam menghadapi persalinan untuk penelitian lebih lanjut.

\section{DAFTAR PUSTAKA}

Ahmad, 2014. Kehadiran Suami Mengurangi Rasa Sakit. Di Unduh Dari : www.kaltimpost.net. Di Akses Tanggal 13 Februari 2016. Jam 13.56 WIB

Amalia, 2009. Buku saku untuk Mahasiswa Bidan. Jakarta : Rineka Cipta

Arikunto, 2010. Prosedur Penelitian Suatu Pendekatan Praktek. Jakarta: Rineka Cipta
Bobak, 2010. Keperawatan maternitas. Edisi 5. Alih bahasa Wijayarini, M.A \& Anugerah, P. I. Jakarta: EGC

Bramantyo, 2011. PerubahanPerubahan pada Kehamilan. Jakarta : Preneda Media

Capernito, 2009. Buku Saku Diagnosis Keperawatan. Jakarta : Rineka Cipta.

Depkes RI, 2015. Promosi Kesehatan bagi Petugas Kesehatan. Jakarta

Dinkes Provinsi Bengkulu, 2015. Profil Dinas Kesehatan Provinsi Bengkulu.

Heri, 2010. Hubungan Krakteristik dan Tingkat Pengetahuan ibu primigravida trimester III dengan Persiapan Menghadapi Persalinan di Wilayah Puskesmas Kecamatan Kembang Kabupaten Jepara. Skripsi Universitas Muhammaiyah Semarang.

Hawari, 2013. Manajemen Stres, Cemas dan Depresi. Jakarta: Balai Penerbit FKUI

Kartini, 2010. Manajemen Kebidanan. Jakarta : Preneda Media

Manuaba, 2010. Ilmu Kebidanan, Penyakit Kandungan dan Keluarga Berencana untuk Pendidikan Bidan. Jakarta : EGC

Maulana, 2013. Ilmu Keperawatan Dasar. Jakarta : EGC

Mochtar, 2014. Sinopsis Obstetric. Jakarta : EGC

Nursalam, 2011. Konsep dan Penerapan Metodologi Penelitian Ilmu Keperawatan skripsi, Tesis dan Instrument Penelitian Keperawatan. Jakarta: Salemba Medika

Notoatmodjo, 2010. Kesehatan Masyarakat, Ilmu dan Seni. Jakarta : Rineka Cipta

Poverawati.A, 2015. Ilmu Gizi untuk Perawat. Jakarta : Nuha Medika

Pusdiknakes, 2014. Promosi Kesehatan bagi Petugas Kesehatan. Jakarta

Purwaningsih, 2012. Asuhan Keperawatan Maternitas. Yogyakarta : Nuha Medika

Sarwono, 2010. Ilmu Bedah Kebidanan. Jakarta: Yayasan Bina Pustaka

Simkin, 2012. Panduan Lengkap Kehamilan, Melahirkan, dan Bayi Edisi Revisi ke-3. Jakarta: Arcan.

Panduan Lengkap Kehamilan, Melahirkan, dan Bayi Edisi Revisi ke-2. Jakarta: Arcan. 
Suliswati, 2010. Konsep Dasar Keperawatan Kesehatan Jiwa. Jakarta : Rineka Cipta.

Soewandi, 2013. Kecemasan atau Ansietas. Di Unduh Dari: www.Mitrariset.blogspot.com. Diakses Tanggal: 13 Februari 2016. Jam 21.10 WIB

Suririnah, 2009. Buku Saku Kebidanan untuk Mahasiswa. Jakarta: Arcan.

Sarwono, 2010, Buku Panduan Praktis Pelayanan Kesehatan Maternal dan Neonatus, Jakarta : PT Bina Pustaka

Supriyono, 2012, Ilmu Fisikoterafi untuk Tenaga Kesehatan. Jakarta: Rineka Cipta

Taufan, 2011. Patologi dan Fisiologi kehamilan. Yogyakarta: Fitramaya

Winkjosastro, 2012. Ilmu Kebidanan. Edisi ke-2 Jakarta: Yayasan Bina Pustaka

Yongky, 2012. Asuhan Pertumbuhan Kehamilan, Persalinan Neonatus, Bayi dan Balita. Yogyakarta : Nuha Medika 